\title{
ARTICLES
}

\section{THE CENTRAL ASIAN SECURITY ZONE B.Baabar}

\section{Current Trends in Asia and the World}

The collapse of the Communist world meant the termina-tion of the cold war which lasted more than forty years after the end of World War II. The termination of the cold war implied the end of the division of the world into a Communist bloc and an anti-Communist bloc. It did not, however, put an end to other division based on military, economic and religious interests. The formal breakdown of the USSR at the end of 1991 marked the funeral for the old divisive system and the beginning of new divi-sions. Although it is still too early to define the new divisions pre-cisely, the past three years have seen a number of important events that indicate major trends. I would like to describe some of these trends.

The breakdown of the USSR created conditions for the United States to become the only power in the world able to re-solve global issues arbitrarily without any major opposition. This was demonstrated by such events as the Persian Gulf war, the conflict in the former Yugoslavia, and the pressure placed upon North Korea and other countries. The United States has a great interest in preserving the present situation. Despite promises made by President Clinton, the first post-cold war president, to con centrate on domestic affairs, it has become clear that the United States has no intention to retreat from its present position of su-periority.

The disintegration of the USSR passed its lowest point, and a trend has emerged toward reunification under the leadership of the Russian Federation. Ambitions to recreate the old Russian empire devoid of Communist ideology have been gaining ground.

The inability of the new states to survive independently and the reality of economic interdependence created under the USSR serve to intensify this trend. At the same time, the leadership of the Russian Federation has refused to renounce old imperial poli-cies, as illustrated, inter alia, by the pressure exerted on Georgia to join the Commonwealth of Independent States. Russia's ef-forts, however to regain the global role that the USSR had played have run counter to the interests of Europe, Japan, the United States, and the Islamic world.

Although the centrifugal ambitions of China's national minorities have received a boost by the disintegration of the USSR, an even more powerful 
tendency is toward economic integration of the countries within the Sinitic cultural sphere in the Pacific region. It is true that China's growing military power has elicited misgivings by the United States, Japan, the ASEAN countries, and China's other neighbors, but at the same time China's economic explosion has exerted such magnetic force on these countries that they have found themselves quite unable to refrain from making major capital investments there. China is doing its best to fill the vacancy left by the USSR as the sole military and economic counterbalance to the United Sates. However, as long as American supremacy remains a reality, China does not want to taint its relations with other countries.

Japan, having become one of the leading investors in an economic rebirth of China, is now having second thoughts about China possibly becoming too strong. However, should it ever become necessary, Japan would be ready to swap the American nuclear umbrella for a Chinese one? As to its relations with Russia, Japan does not intend to make any dramatic improvements in the foreseeable future. Japan has also displayed its desire to over take both the United States and China as the leading power in the recently established Asian-Pacific Economic Council (APEC). It does not support the extension of European interests into the Asian-Pacific region.

United Europe, established by the Maastricht Treaty, is ex-panding its boundaries to encompass Eastern Europe as well and is getting ready to compete with the countries of the Pacific. Al-though its economic potential is comparable to that of the United

States, Japan, or China, given its present rate of economic growth, Europe could soon be surpassed by others. As a consequence, Europe looks with interest to Russia and the entire former USSR as a launch pad for its interests. If Russia's interests should at some point overlap Europe's, there is a chance for Russia to join Maastricht Europe.

The end of the Afghan war and the disintegration of the USSR have presented the Islamic world with new opportunities but have also deprived it of a possibility to play one system against the other. This was clearly demonstrated by the Persian Gulf War and the unusually successful Israeli-Palestinian negotiations which had been impossible during the last forty years or more. The for-mation of new Islamic countries in the former Soviet Central Asia, rich in natural resources and a highly literate population, has pro-duced a desire to draw them either into the fundamentalist Is-lamic camp of Iran, Afghanistan and Iraq, or into the political orbit of Turkey which represents the interests of the United States and Europe. 
In addition, the following political and economic tendencies have been observed.

a. The collapse of the USSR has caused many states to abandon Communism as their political and economic doctrine. Countries like India and Bangladesh who for many years had been following socialist-style economic and public policies have bandonned them in favor of capitalist practices.

b. The South Korean and Taiwanese development model, with its mixture of an authoritarian political system and liberal economic policies, has attracted much interest in underdevelopedopted countries. In the nearest future, some African and Latin American countries may well try to emulate that model.

c. There has also been a general trend to opt for a democratic political system.-This is being observed not only in the former constituent republics of the USSR and in Soviet-bloc countries but also in Asia, South Africa, and Latin America. It is likely, however, that the most impoverished states may well bandon this trend in favor of more authoritarian forms of government.

d. Another important phenomenon is the return of ex-Communists to power through democratic electoral processes. This is partly explained by economic difficulties encountered during the transition period to a market economy, and partly by the fact that these ex-Communists have been effective in appealing to the general public by exploiting nationalist sentiments. They clearly prefer the South Korean and Taiwanese model, and if it should prove successful, one can expect a form of authoritarianism a La Pak Chung-he installed for a considerable period of time.

e. Attempts to find a third way of development, pursued by Socialists and Social Democrats, both in power and in opposition in many democratic countries, have mostly ended up in capitalistic policies. The political platforms of major Social Democratic parties can now be hardly toad apart from those of bourgeois parties, and Socialists are trying to shake off the hold of trade unions by introducing changes in their political philosophies and political activities.

The twentieth century has witnessed some colossal changes in the conduct of human affairs. At the beginning of this century, ideological, economic, military, social and religious trends were drifting toward the political Left, and now, as we are nearing the end of the century, these trends are decidedly in the opposite direction. The number of militant religious believers has increased manifold over that same period to time. But perhaps the greatest change has been the recent red vision and realignment of the world as a consequence of the end of the cold war. Greater than the red visions after both world wars and more far-reaching than even the decolonization of Africa in the 1960s, the end of the 
USSR not only created countries that had never been independent before but also presented them, and many other countries, with a range of choices not available at any time earlier in the twentieth century. This is an opportune, almost divine moment for the world's smaller and newly independent countries to lay the foundations for their future. What they do, and do not do, now will have consequences lasting not only decades, but perhaps centuries.

Mongolia has been affected by this great historical moment as much as any other country. Some seventy years ago, during another period of red vision, Mongolia regained its place on the world's political map, albeit under the strong influence of the USSR.

Today, Mongolia has experienced a rebirth of sorts. Freed from the constraints put upon it in the past, Mongolia now must choose from an unprecedented wide range of options. Some only see the immediate problems and seek to alleviate the current economic crisis by any and all means, including inconspicuously begging for help from any and all countries. Others meet the challenge by excessively theoretical discussions. Still others advocate the cur-rently rather popular notion of placing Mongolia under the Ameri-can "umbrella." When it comes to considering the implementa-tion of the latter notion, however, it loses its appeal. This is be-cause identifying America's interest in Mongolia is akin to looking for a needle in a haystack out in the Droned Steppe. Finally, in more recent times, an opinion has gained popularity that focuses on Mongolia's geographical position of being between Russia and China. Essentially, the opinion posits that inasmuch Mongolia's position will never allow complete independence from either of its two neighbors, it would be best to resubmit to Russian hegemony. China's recent economic expansion into Mongolia has gained converts to this opinion.

There is another option that ought to be seriously considered, namely regional security systems. Aside from such extraordinary cases as Israel and Kuwait, smaller nations have sought to ensure their security in regional arrangements. There have been the American- dominated military pacts during the cold war, like CENTO, SEATO, and NATO. Other kinds of associations include the OAS for the Americas and the AU for Africa, and more recently ASEAN for Southeast Asia, and the European Community.

It is this kind of regional security arrangement that may be the best safeguard for Mongolia's future. It is, of course, by no means easy to determine to which region Mongolia belongs. For decades it belonged to a regional security system that stretched from its own southern border all the way to the Berlin Wall. Even though the USSR has disappeared, relations forged over many years 
between Mongolia and other formerly Socialist states should be maintained and developed, but these relations are not likely to be of much help for Mongolia's security needs.

Another possible regional arrangement from which Mongolia might derive benefits lies in the Asia-Pacific, or Pacific Rim, region which is very much in the limelight these days. The organi-zation which recently emerged there, the Asian-Pacific Economic Council (APEC), is, as its name clearly states, an exclusively eco-nomic arrangement and therefore of no help for Mongolia's se-curity needs. In any case, given its geographical location, Mon-golia is ineligible to join APEC, although, if it applied, it might be admitted as a token member.

Finally, there has recently been a flurry of speculation in Mongolia about Northeast Asia. Its geographical extent is rather uncertain, given the fact that publications include such dissimilar countries as the two Koreas, Japan, China, Russia, and the United States. Whatever the merits and potentialities of a Northeast Asian association may be, they most assuredly could not include the kind of security Mongolia needs.

To my way of thinking, none of the above-mentioned arrangements, hold out any hope for Mongolia, mainly because geographically, historically, and culturally, Mongolia is not a Pacific country but belongs to Central Asia.

\section{What is Central Asia?}

The Mongolian words for Central Asia and Middle Asia are crude translation of the Russian terms Tsentral'naya Aziya and Srednyay Aziya, respectively. Since the time of Przhevalskij, the term Tsentral'naya Aziya used to incorporate Tuva, Mongolia, Xinjiang, Tibet and Afghanistan, all located deep in the heart of the Eurasian continent. In order to semantically separate the Turkic portions of the Russian empire from the rest of Central Asia, the term Srednyaya Aziya was coined and applied to that region. Thus, while in the rest of the world, Asia's entire interior was called Central Asia, in Russia, what belonged to Russia was called Middle Asia, and what did not belong, was called Central Asia.

We ought to make a clean break with past practices and, like the rest of the world, use the single term Central Asia. Using mostly geographical criteria, we include in this region Mongolia, Southern ("inner") Mongolia, Tibet, Xinjiang, Tadjikistan, Turkmenistan, Uzbekistan, Kyrgyzstan, Kazakhstan, Buryatia, Tuva,

And the autonomous regions of the Aginsk Buryats, Khakass, and the Altai Mountain groups. One might even go so far as to include Afghanistan, Azerbaijan, Kurdistan and Nepal, but areas mostly inhabited by Caucasians, like Siberia, are not included in the concept of Central Asia. 
Within this vast region, there is considerable topographical variety, including deserts, high mountains, and large stretches of agricultural land. In the realm of culture, Central Asia was in the remote past the place of confluence for some of the world's major religions, including Christianity, Buddhism and finally Islam. Likewise, with many different people moving into the region, considerable ethnic and linguistic diversity ensued, resulting in major representation of the three large linguistic families of Indo-European: Sino-Tibetan, and Altaic. Over time, this diversity became considerably whittled down, with Christianity virtually disappearing, Buddhism confined to the easternmost parts of the region, in Mongolia and Tibet, and Islam becoming the dominant religion in all the rest of Central Asia At various times in the past, this great diverse region was politically unified, first under Alexander the Great, then by Chingis Khan, Hulegu and Timur (Tamerlane). Later on, as ethnic, linguistic, and religious diversity declined, so did political unity.

The disintegration of the USSR and the establishment of new states have led to the creation of a new political region of Central Asia. If the region is considered in purely political terms, both Russia and China, along with their territories of Tuva, Buryatia, Tibet and Xinjiang, must be excluded because Russia's political center is in Europe and China's along the Pacific coast. Therefore, today's political Central Asia includes Mongolia, Afghanistan, Kazakhstan, Tajikistan, Uzbekistan, Azerbaijan, Turkmenistan, and Kyrgyzstan.

Political Central Asia has several features in common. Apart from Mongolia, all countries are Sunni Moslem nations. The dominant ethnic and linguistic group is the Altaic one. It constitutes 20 percent of the population in Afghanistan, 25 percent in Tajikistan, 40 percent in Kazakhstan, 60 percent in Kyrgyzstan, 70 percent in both Turkmenistan and Uzbekistan, 80 percent in Azerbaijan, and 100 percent in Mongolia. All Central Asian countries, including Afghanistan and Mongolia, were under Russian and Soviet tutelage throughout most of this century. Compared to countries like Japan and the United Stats, this vast region is one of the most backward areas on this planet. !t is almost en-tirely devoid of any modern infrastructures. Yet, thanks to Soviet influence, it also enjoys relatively high literacy rates and a sizable corps of trained professionals. Also on the positive side are huge mineral resources which so far have hardly been explored and prospected. Finally, urbanization, while still relatively low, is growing sharply, driven by one of the world's highest population growth rates.

One should, in my opinion, add to the list of countries in political Central Asia the forty million people of Turkey. It is true that over the last five to six hundred years, Turkey has held an ambiguous position between Europe and the 
Middle East and that it has been variously included in the Mediterranean, Balkan, Middle East, European, and Islamic areas. Nevertheless, there are two reasons arguing in favor of such inclusion. More than one thousand years ago, the ancestors of the Turks moved from what was considered traditional Central Asia to settle down in Asia Minor, the site of the ancient civilizations of Babylon and Byzantium. The other reason is that the Turks have maintained their traditional ties with the peoples of their ancestral homeland.

With the inclusion of Turkey, Central Asia spans some and is beginning to emerge as a new political phenomenon.

\section{Common Interests of Central Asian Countries}

In addition to the common features just described, the Central Asian countries also share major interests such as security, geopolitics, and economics. Here is a brief description of these interests in each major country of Central Asia.

\section{Turkey}

Of all the countries in this region, only Turkey has been able over the past two centuries to maintain its independence and national interests. Between the fall of he Ottoman empire at

The end of the First World War and the establishment of NATO after the Second World War, Turkey had to stand on its own against any potential aggressor. Today, being the only Moslem nation within NATO, Turkey is faced with Kurdish and Armenian separatist movements, and its own Islamic fundamentalists enjoy the sym-pathy, if not actual support, of its neighbors. As a consequence of the breakdown of the USSR, Armenia and Georgia, Turkey's traditional enemies, have become independent. In addition, in Russia, Zhirinovsky, who has publicly declared that he would not recognize Turkey's sovereignty, has begun to exert considerable influence on Russia's foreign policy? To the west, another Balkan crisis has broken out and may become a serious security threat to Turkey. Its long-standing conflict with Greece, another NATO member, over Cyprus may under present circumstance idea to a result unfavorable to Turkey. All in all, Turkey has at present not entirely amicable relations with Armenia, Georgia, Russia, and the successor states to the former Yugoslavia, Rumania, Bulgaria, Cyprus, and Greece. Even less friendly relations are maintained with the Islamic fundamentalist countries of Syria, Iraq and Iran who are opposed to Turkey's moderate politics and Western-style developmental model. It is for this reason that two years ago the then-President Ozal and the 
current President Demirel started to search for ways to create a Turkic community of nations to be led by Turkey. Ozal's untimely death, however, stalled efforts in that direction.

\section{Azerbaijan}

This Turkic nation which was first formed between the eleventh and thirteenth century had been the object of contention between Iran and the Ottoman Empire until Russia and Iran divided the country between them. In our own time, it was in Azerbaijan where the first national conflict broke out before the fall of the USSR. Being the only Turkic and Moslem nation in the Caucasus, it has always been at odds with Christian Armenia and Georgia. During the recent. Karabakh conflict between Armenia and Azerbaidjan, Russia, which initially tried to resolve the conflict impartially, eventually sided with Armenia. Iran, its southern neighbor with several million Azeri residents, views an independ-ent Azerbaidjan with a considerable degree of suspicion. This feeing was strengthened when the Turkish prime minister verbally supported Azerbaijan in its struggle against Armenia which led many Azeris to believe that their salvation lay with Turkey rather than Russia or Iran. Strained relations with and rivalries among its neighbors are still further exacerbated by Azerbaijan's large re-sources of oil and other minerals.

\section{Uzbekistan, Turkmenistan, and Kyrgyzstan}

Although the Uzbeks were among the last to form a nation in Central Asia, they established one of the most developed civi-lizations there. Similarly, today Uzbekistan has the highest literacy and urbanization rates in Central Asia. It also has the largest popu-lation, with Uzbeks constituting about 70 percent. Persian influ-ence is dominant. The Turkmen constitute 70 percent of the popu-lation of Turkmenistan. It is one of the most underdeveloped ar-eas in the world, and it has the lowest population density in Cen-tral Asia. The Kyrgyz are an ancient nomadic nation. At present, they constitute more than half of Kyrgyzstan's population and the Uzbeks another 15 percent, while Russians and Ukrainians account for most of the remaining 35 percent. With independence having been bestowed upon them from the center in Moscow, they rely heavily on Russia for their security and support Ozal's proposal only on economic grounds.

\section{Kazakhstan}

The Kazakhs have been exposed to European influences more than any other Central Asian people, and they constitute only one third of Kazakhstan's 
population, with Russians and other Europeans accounting a full 60 percent. In fact, the northern portions of the country are overwhelmingly non-Kazakh in their ethnic composition. Besides, the former USSR built major economic and military installations, most notably at Semipalatinsk and Baikonur, as well as developed huge tracts of agricultural land. It is small wonder, then, that Russia expressed its displeas-ure when Kazakhstan made its first moves to secede from the

USSR. All of the assets mentioned above, as well as President Nazarbaev's charismatic appeal, have contributed to Kazakhstan's desire to play first fiddle in Central Asia, and until now it has been successful in this regard. Notwithstanding the umbilical that still ties Kazakhstan to Russia, there is a strong desire to develop closer relations with other nations in the world, particularly the United States.

\section{Tajikistan}

In Tajikistan, the most unstable country in Central! Asia, the Tadjiks make up about 60 percent of the population. Despite having a majority, the Tadjiks are torn apart by a protracted con-flict between southern and northern tribes that has escalated into a full-scale civil war. The Tadjiks are the only non-Turkic nation in former Soviet Central Asia. Being part of the Persian world, they have historical, cultural and traditional ties with Iran and Afghanistan. On the other hand, many Tadjiks, especially the better educated ones, oppose any close relations with the two countries who are presently in the grip of Islamic fundamentalists. It is the moderates' conviction that only Russia can offer protection against the fundamentalists' designs on Tajikistan and at the same. Time serve as a stabilizing force within the country.

\section{Afghanistan}

Since 1747 when it separated from Iran, Afghanistan has been a multiethnic country where the Pushtu, who is of Persian ancestry, forms the majority. In addition, several Turkic groups live there, among them Uzbeks, Turkmen, and Kyrgyz who among them make up 40 percent of the population. During the last one hundred years, the Afghans have managed to defeat three British attempts at invasion and, more recently, a concerned Soviet effort to maintain a Sovietstyle government in Kabul. At the present time, the grip of the fundamentalists totally dominates life in the country, and to a certain extent influences its external relations. It is not surprising, of course, that Afghanistan has disputes with Russia and Tajikistan, but strained relations also exist with Paki-stan and Iran. 


\section{External Countries and Central Asian Security}

\section{Russia}

From a geopolitical point of view, Russia would not wel-come the creation of a Central Asian political and security zone. The main reason for this is that, with the exception of Turkey, all countries in this region share the same military interests as Rus-sia, and Russia is not willing to let Central Asia slip from its sphere of influence. Taking into consideration the major power changes taking place in Asia, it is to Russia's distinct advantage to keep the Central Asian countries as its southern shield against the fundamentalists in Iran and Afghanistan as well as against China with which Russia has had serious border problems in the recent past. Moreover, Russia is very interested in this region's natural wealth.

\section{China}

The creation of a buffer zone in Central Asia by Russia would also be in China's interest, not only for military and strategic reasons, but also to insulate its own Turkic nationalities in Xinjiang from the corrosive influences of the Muslim fundamentalists in Iran and Afghanistan. Beyond this, economic reconstruction 3rd the development of infrastructures in Central Asia would also benefit China's efforts to increase economic growth its western regions which are lagging behind the more dynamic provinces along China's Pacific coast.

\section{United States}

The United States would be the primary beneficiary of a security zone in Central! Asia. If the United States were able to exert sufficient political, economic, and military influence in the region, it would be in a position to better monitor events there where the interests of Russia., China, and the Islamic world con-verge.

\section{Europe}

The formation of the Asian-Pacific economic and political region has left Europe shocked and bewildered. Europe is facing the danger of being left out from the process of economic growth and cooperation that is presently mushrooming in the Pacific re-gion. Japan, China, and the United States are not willing to let Europe actively participate in this process, with the United States explaining its participation in terms of providing a counter-balance to its historically heavy involvement in European affairs. It is in Europe's vital interest to 
open new doors in Asia, and if it cannot do it on Asia's Pacific coast, then somewhere closer to Europe might be possible. Central Asia would serve admirably well as Europe's door to Asia. If Europe were to become the major player in that region and be able to monitor the process there, it would be in a good position to penetrate the Chinese market from the west and the north and deal a blow to the Japanese "zone of defense". Germany, the leading economic power in Europe, was the first to advance the idea of a Central Asian zone through Turkey's good offices two years ago. The German idea of a union of six Turkic nations with promises of economic aid from Turkey revealed the great extent to which German and Turkish interests in Central Asia overlapped.

There are several important factors stimulating European interest in the region. Being fully dependent on Middle Eastern oil supplies, Europe has been entertaining hopes of acquiring another source of energy supplies on the territory of the former USSR. If this new source were ever to fall into the hands of Islamic fundamentalists, there would be a danger of increased European dependency on the Islamic world. Another danger is a possible "brain drain" from Central Asia, where during Soviet times a highly trained scientific work force had been created, into the Islamic world. The greatest danger, however, lies with Kazakhstan's nuclear weapons potentially slipping out international control at a time when Russia is in turmoil. Most recently, this danger was fortunately alleviated when American planes took a shipment of nuclear weapons-grade material out of the region.

Germany has the capacity to influence the course of events in Central Asia. Apart from being a fellow NATO member, Turkey looks upon Germany as its major economic partner in Europe. At the other end is Kazakhstan which has a considerable community of ethnic Germans. Mongolia, which maintained a substantive network of relations with East Germany, is another Central Asian country whose potential to play an important role in the region is understood by Germany. This is all the more true in light of the fact that, unlike other Central Asian countries, Mongolia is a politically stable society and has a comparatively democratic political regime.

\section{Japan}

Mongolia is the only ally that Japan has in the Central Asian region. It is a convenient route for penetrating the markets of Eastern Siberia and Northern China. However, over the past four years Japan has become increasingly disappointed by the ineffective and inert Mongolian government. As a consequence Japan has begun efforts to revive its Central Asian policy by relying more on 
countries west of Mongolia, such as Kazakhstan and Kyrgyzstan. Japan is averse to the prospects of unilateral domination of the region, be it Chinese, Russian, or European.

\section{Conclusion}

Central Asia is one of the most insular and backward areas in the world. Its economic development is hampered by such natural factors as remoteness from the sea, location in the heart of Eurasia, a dispersed population, mountain ranges unfit for building infrastructures, vast steppes and deserts, and an almost constant lack of precipitation. Mineral resources have not been explored on a large scale which accounts for a lack of precise information on the region's economic potential. At the same time, however, this very lack of reliable information has revived speculation about a new "promised land". As new operations have been started on Kazakhstan's Tengiz oil deposits, Turkmenia's natural gas, and Azerbaijan's oil, this speculation has soared. Although developing the region will require billions of dollars in investment, once political stability is established, any power would be able to reap political and economic fruits.

The idea of a Central Asian security zone is certainly not the only way of safeguarding Mongolia's national interest, and it may not even by feasible. But from several perspectives, this idea, which involves a number of important international factors, de-serves serious consideration.

At present, Central Asia does not yet represent an economic or geopolitical entity. Although President Ozal was unable to see the completion of his initiative, it ought to be pursued. It is a goal that, under certain conditions, can be attained. One condition is that Russia China, and the United States respect a Central Asian security zone. The other condition is that Mongolia be an active participant in such a security zone. Mongolia has an abiding interest in seeing the creation of a Central Asian security zone. Throughout their history, the Mongols had been leaders of Turkic nations, and both Mongolia and Turkey have set examples; as independent states for other nations in the region to emulate. 